\title{
Assessment of Nearshore Wave Climate off the Southern Coast of Sri Lanka
}

\author{
P.P. Gunaratna, D.P.L. Ranasinghe and T.A.N. Sugandika
}

\begin{abstract}
Numerical modelling of wave propagation was carried out to assess the variability of nearshore wave climate off the southern coast of Sri Lanka. The modelling was based on the application of MIKE 21 SW (FM) model in a domain covering the entire southern coast and part of the south-eastern coast of Sri Lanka, with the offshore boundary located in the deep sea. Based on model results, a wave transformation matrix approach was used to transform the available wave data from three past wave recording locations, to desired locations. Swell and sea wave systems were considered separately with appropriate wind fields introduced to model sea wave propagation. The study resulted in the establishment of nearshore wave statistics on a seasonal basis for coastal sectors along the model domain. These wave statistics are useful in obtaining necessary design parameters for any planned coastal and marine structures within these coastal sectors through the application of local area models.
\end{abstract}

Keywords: Waves, Sea, Swell, Nearshore

\section{Introduction}

The economical and safe design of coastal and harbour structures require a realistic assessment of wave conditions they will be subjected to during their life time. The structures need to be designed to withstand extreme wave conditions that they will be exposed to during their lifetime. Waves and wave induced currents are the primary sea motions causing transport of sediment in the nearshore areas. The associated beach profile and coastline changes result in erosion and or accretion along coastlines. In order to predict such changes, knowledge of year round variability of nearshore wave climate is required. The evaluation of effectiveness of any coastal stabilization scheme designed to control coastal erosion also requires a proper assessment of wave climate.

The information on seasonal or annual wave climate and extreme wave occurrences can be obtained in this long term with an instrument engaged for wave recordings in the sea. However, it is not feasible to undertake wave recordings at all locations where such data are required. Instead, the most prudent approach is to conduct wave recordings at selected few locations and transform these wave data to any other desired location. This objective can be achieved by numerical wave propagation modelling, considering variation of sea bed bathymetry.
In this paper, a research study carried out to establish nearshore wave climate along the southern coast of Sri Lanka using numerical wave propagation modelling is presented. The approach adopted makes optimal use of wave recordings available from few locations. The study area of interest is divided into segments where nearshore wave climate on an annual and seasonal basis is obtained for all segments. The extreme wave occurrences are also determined by extrapolation of wave statistics. The outcome of this study constituted a useful wave database for coastal engineering studies for future implementation of developments in the coastal zone along the southern coast of Sri Lanka.

\section{Wave Conditions off the Southern Coast}

The wave climate off the southern coast of Sri Lanka is characterized by the year round

Eng. (Dr.) P.P.Gunaratna, B.Sc. Eng. (Moratuwa), C. Eng., MIE(Sri Lanka), M.Eng. (AIT), Ph.D. (Clarkson), Marine Projects Specialist, Coastal Zone $\mathcal{E}$ Waterways Management Section, Dubai Municipality, Dubai, UAE.

Eng. D.P.L. Ranasinghe, B.Sc. Eng. (Ruhuna), AMIE(Sri Lanka), M.Sc. (Moratuwa), Ph.D Candidate, Graduate School of Engineering, Tohoku University, Japan.

Eng. Miss T.A.N. Sugandika, B.Sc. Eng. (Ruhuna), AMIE(Sri Lanka), Engineering Manager, Lanka Hydraulic Institute, Katubedda, Moratuwa. 
occurrence of long period swell waves and local wind generated short period sea waves, mainly of monsoonal origin. The swell waves are those waves generated in the southern Indian Ocean and have propagated out of the generation fetches. These waves approach from a more or less southerly direction in deep water. The most violent and significant sea waves are locally generated due to south west monsoonal winds. These waves are still being generated by wind fields when approaching nearshore coastal waters. Although southern coast is not directly influenced by north east monsoonal weather, the waves generated by those wind fields affect the south eastern part of the southern coast at a reduced strength. These waves in particular effect the safe navigation and anchorage of fishing crafts.

The seasonal variability of the wave climate off the southern coast causes spatial and temporal changes in sediment transport and coastlines. The most violent sea conditions are observed during the south west monsoon season during which both sea and swell waves occur at maximum strength. In the south eastern part which is affected by both monsoonal sea waves, severe sedimentation problems are possible with Kirinda fishery harbour being a classical example.

\section{Instrument Wave Recordings}

Instrument wave recordings have been conducted off the southern coast of Sri Lanka since 1984 over intermittent periods (Figure 1). These wave measurements may be broadly classified into non-directional recordings (those in which only wave height and wave period parameters are measured) and directional recordings (in which wave direction is also measured). Table 1 (LHI, [2]) summarizes the available wave data from instrument wave recordings in Southern Sri Lanka.

The most comprehensive wave data base available for the southern coast is that due to the directional wave recordings conducted around $70 \mathrm{~m}$ water depth, about $8 \mathrm{~km}$ offshore in Galle, under the CCD/GTZ directional wave climate study (Scheffer, et. al., [3]). Under this wave recording programme, using a pitch and roll type wave profiling buoy, waves were measured over a total duration of around 5 years during the period 1989-95. The recorded raw data had been subjected to spectral analysis and based on a cut-off frequency, the swell and sea wave systems were separated and statistical height, period and direction parameters were obtained, for both wave systems as well as for the overall (combined sea and swell) waves.

Table 1 - The Summary of Available Wave Data in Southern Sri Lanka (LHI, [2])

\begin{tabular}{|l|l|l|l|l|l|}
\hline No. & \multicolumn{1}{|c|}{$\begin{array}{c}\text { Location/Dept } \\
\mathbf{h}\end{array}$} & \multicolumn{1}{|c|}{ From } & \multicolumn{1}{|c|}{ To } & \multicolumn{1}{|c|}{ Instrument } & Data Type \\
\hline 1. & Galle(23m) & $\begin{array}{l}\text { Sep 1984 } \\
\text { Sep 1988 }\end{array}$ & $\begin{array}{l}\text { Aug 1986 } \\
\text { Aug 1995 }\end{array}$ & Wave Rider Buoy & $\begin{array}{l}\text { Non- } \\
\text { Directional }\end{array}$ \\
\hline 2. & Galle (70m) & $\begin{array}{l}\text { Feb 1989 } \\
\text { May 1994 }\end{array}$ & $\begin{array}{l}\text { Sep 1992 } \\
\text { Sep 1995 }\end{array}$ & $\begin{array}{l}\text { WAVEC Pitch and Roll } \\
\text { Buoy }\end{array}$ & Directional \\
\hline 3. & Galle (23m) & Jun 1990 & Jul 1990 & Marsch McBirney ECM & Directional \\
\hline 4. & Galle (17m) & Jan 1999 & Mar 1999 & Inter Ocean S4DW ECM & Directional \\
\hline 5. & $\begin{array}{l}\text { Kudawella } \\
(15 \mathrm{~m})\end{array}$ & Jan 1996 & Feb 1997 & Inter Ocean S4DW ECM & Directional \\
\hline 6. & $\begin{array}{l}\text { Tangalle (16m) } \\
7 .\end{array}$ & Kay 1986 & Sep 1986 & Wave Rider Buoy & $\begin{array}{l}\text { Non- } \\
\text { Directional }\end{array}$ \\
\hline 8. & $\begin{array}{l}\text { Kirinda (20m) } \\
\text { (20m) }\end{array}$ & May 1988 & Mar 1989 & $\begin{array}{l}\text { Wave Rider Buoy Marsch } \\
\text { McBirney ECM }\end{array}$ & Directional \\
\hline 9. & $\begin{array}{l}\text { Hambantota } \\
(17 m)\end{array}$ & Dec 2002 & Mar 2003 & Inter Ocean S4DW ECM & Directional \\
\hline 10. & $\begin{array}{l}\text { Hambantota } \\
(17 m)\end{array}$ & Apr 2006 & June 2009 & Inter Ocean S4DW ECM & Directional \\
\hline
\end{tabular}




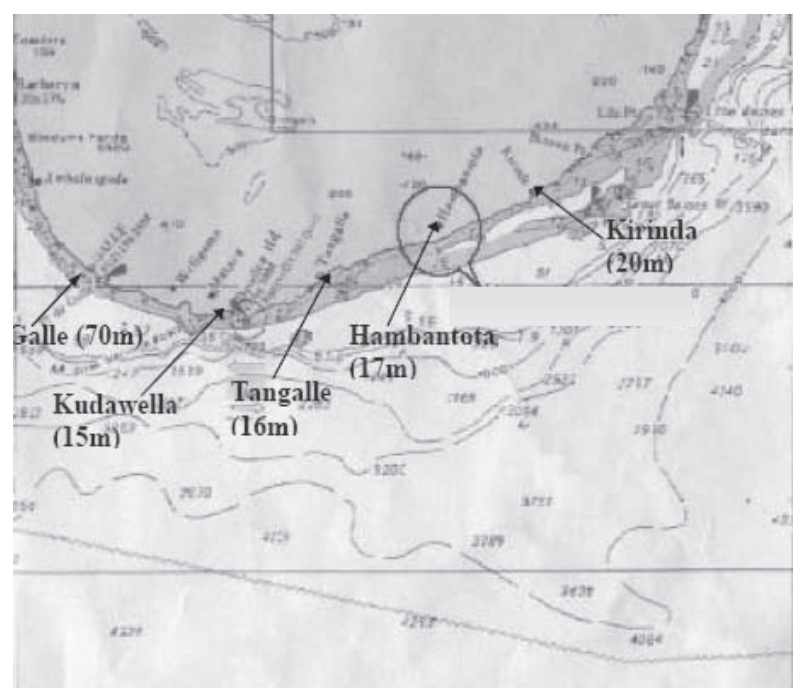

Figure 1 - Locations of Available Wave Data in Southern Sri Lanka

\section{Study Methodology}

The study methodology is based on the application of MIKE 21 SW (FM) model to simulate wave propagation off the southern coast and using a wave transformation matrix approach to transform wave recordings based on model results. The study area was divided into segments bounded by prominent headlands for the purpose of determining nearshore wave climate (Figure 2).
The coastal segments used in the CCD-GTZ directional wave climate study (W1, W2, W3 etc.) were retained as they are and additional segments covering southern and part of south eastern coasts (N1, N2, N3 etc.) were introduced. For each coastal segment, a representative nearshore wave climate was established at $15 \mathrm{~m}$ water depth.

MIKE 21 is a two dimensional modelling system mainly used in coastal engineering applications, developed at Danish Hydraulic Institute, Denmark. It consists of computational modules for hydrodynamics, wave propagation, sediment transport, morphology, advection-dispersion processes etc. MIKE $21 \mathrm{SW}(\mathrm{FM})$ is a spectral wave module within MIKE 21 capable of simulating growth, decay and transformation of wind generated waves and swells in offshore and coastal areas. It is based on an unstructured mesh discretization of the model domain. The wave phenomena accounted for by this module include shoaling, refraction, diffraction, bottom friction, wave breaking, wave growth by the action of wind and wave-current interaction. The conservation equation of wave action is solved by a cell centered finite volume scheme in the model domain which may be discretized into triangular or quadrangular elements. The time integration is performed using a fractional step approach where a multi sequence explicit method is applied for the propagation of wave action.

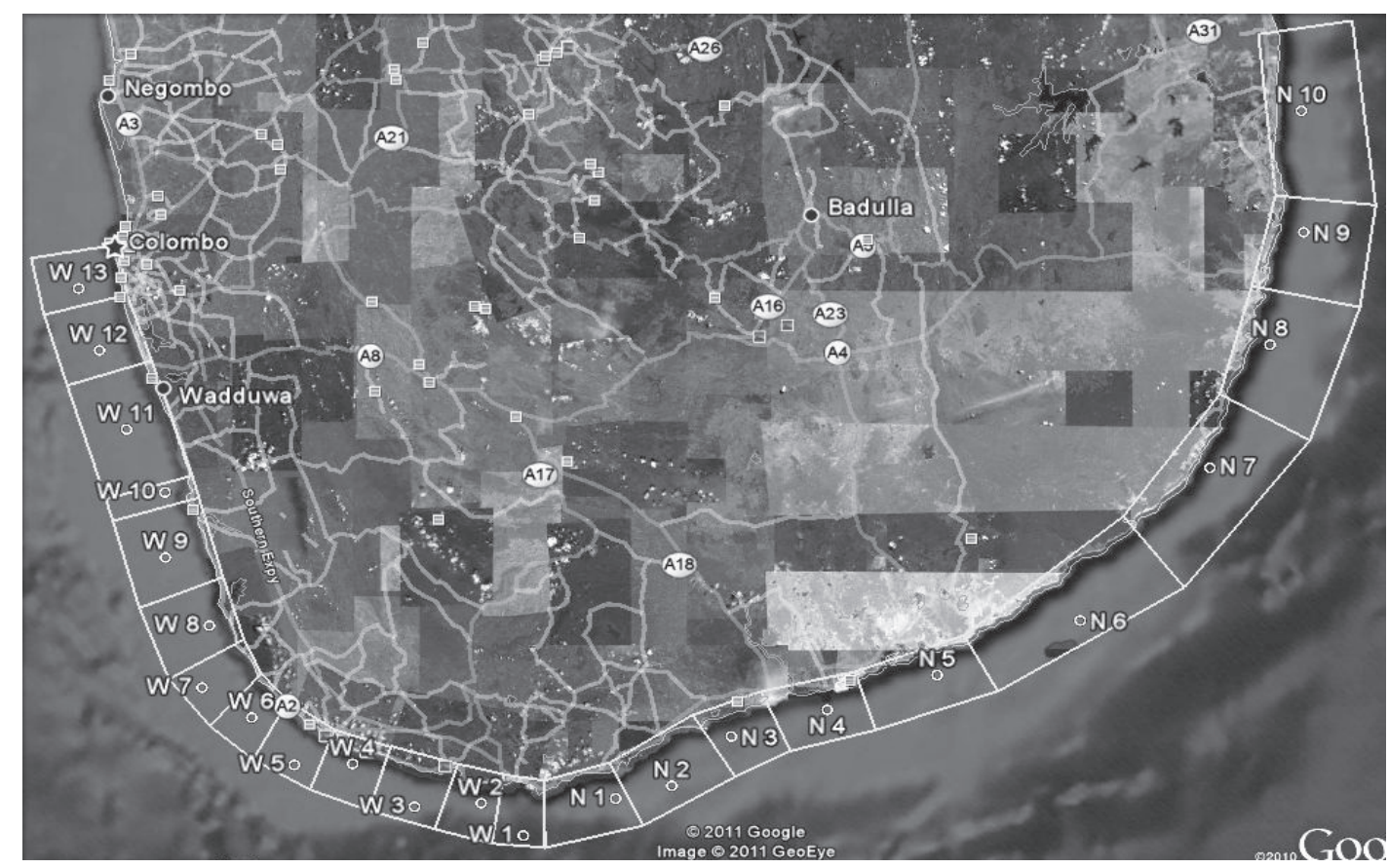

Figure 2 - Coastal Segments Considered for Determining Nearshore Wave Climate 


\section{Regional Wave Model}

The Regional Wave Model for wave propagation simulations was established by digitizing from the Admiralty Charts (3265, 1583 and 813). The extent of the model covered the entire southern coast and part of the south eastern coast as well. The offshore boundary of the model was extended to deep water in excess of $1000 \mathrm{~m}$. The model bathymetry is depicted in Figure 3. A two level mesh resolution was used with a relatively fine resolution adopted in shallow nearshore areas.

\section{Wave Transformation Matrices}

Wave propagation modelling was carried out to transform wave recordings from 3 locations (Galle, Hambantota and Kudawella) to represent locations at $15 \mathrm{~m}$ depth in the selected coastal segments. Since the recording locations are scattered at different water depths, in the procedure adopted, all wave recordings were transformed to the offshore boundary of the model and thereafter transformed back to the desired destination locations. Since transforming several thousands of individual wave recordings is a cumbersome process, a transformation matrix approach functioning on transformation of selected set of wave conditions at the offshore boundary was adopted. A set of wave conditions comprising combinations of following wave parameters were specified at the offshore boundary.

\section{Sea Waves}

Significant Wave Heights: $0.75 \mathrm{~m}, 2.25 \mathrm{~m}, 3.75 \mathrm{~m}$, $5.25 \mathrm{~m}$

Peak Wave Periods: 2s, 3s, 10s

Mean Wave Directions: $60^{\circ}, 70^{\circ}$, $300^{\circ}$

\section{Swell Waves}

Significant Wave Heights: 0.75m, 2.25m, 3.75m, $5.25 \mathrm{~m}$

Peak Wave Periods: 6s, 7s, ............. 20s

Mean Wave Directions: $120^{\circ}, 130^{\circ}, \ldots \ldots \ldots, 240^{\circ}$

In the case of sea waves, they are still being generated by the local wind fields. Data on local wind fields over open sea generating waves are not available. In the absence of such data, in the simulation of sea waves, a wind speed correlated with the offshore significant wave height was applied over the model domain based on Beaufort scale description of marine weather [4] as given in Table 2.

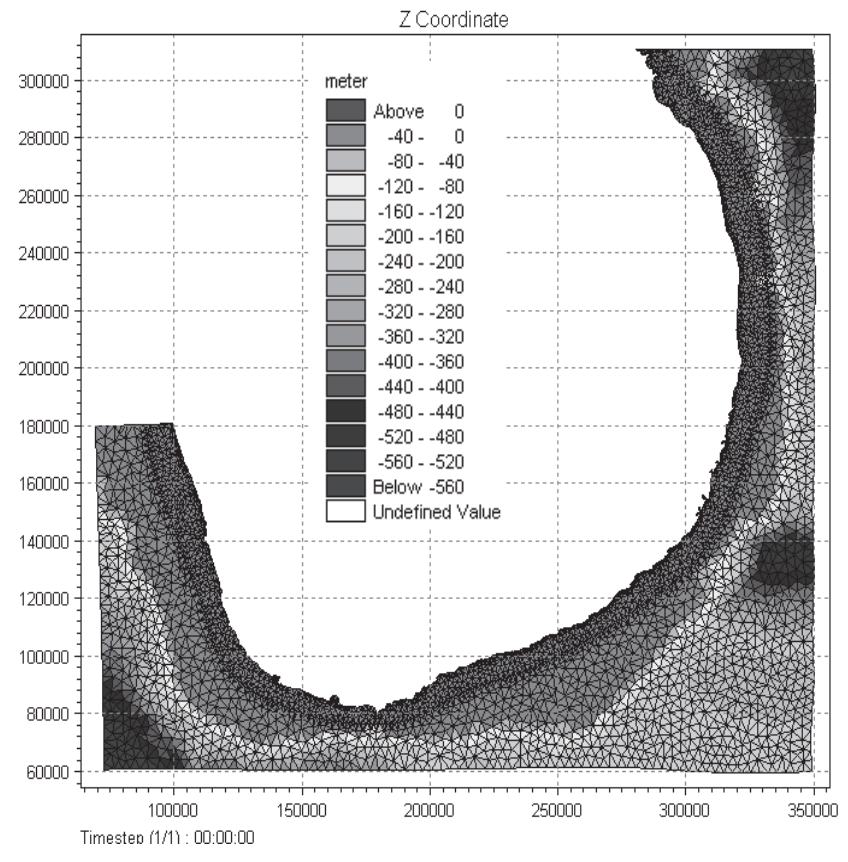

Figure 3 - Regional Wave Model Bathymetry

The wind direction was assumed to be in the same direction as the offshore wave direction over the entire model domain.

Table 2 - Assumed Wind Speeds for Offshore Significant Wave Heights

\begin{tabular}{|c|c|}
\hline $\begin{array}{c}\text { Offshore Significant } \\
\text { Wave Height } \mathbf{( m )}\end{array}$ & Wind Speed (m/s) \\
\hline 0.75 & 4.5 \\
\hline 2.25 & 10.1 \\
\hline 3.75 & 13.4 \\
\hline 5.25 & 16.1 \\
\hline
\end{tabular}

The specified significant wave heights of 0.75 $\mathrm{m}, 2.25 \mathrm{~m}, 3.75 \mathrm{~m}$ and $5.25 \mathrm{~m}$ were assumed to represent offshore significant wave height ranges $0-1.5 \mathrm{~m}, 1.5-3.0 \mathrm{~m}, 3.0-4.5 \mathrm{~m}$ and 4.5 $-6.0 \mathrm{~m}$, respectively. The simulation results for the above specified wave conditions were extracted at source wave data recording locations at Galle, Kudawella and Hambantota as well in all destination locations representing selected coastal segments. These results were then organized into 3 matrices at each location. The rows of these matrices correspond to offshore wave periods while the columns correspond to offshore wave directions. The elements in the 3 matrices consisted of wave height ratios (wave height at extracted location/offshore wave height), wave periods at extracted locations and wave directions at extracted locations. 
Having established the wave transformation matrices, individual wave recordings were transformed to desired locations by interpolating from the transformation matrices. This was a two-way process, in which firstly wave recordings were transformed to offshore boundary and then transformed back to the desired destination location. In the case of sea waves, wave period also changes due to energy transfer from wind. As such, direct interpolation from wave transformation matrices is not possible when transforming source wave parameters to the offshore boundary. This task had to be accomplished iteratively starting with the initial assumption that offshore wave period is same as that recorded at the source wave data location. Due to non-convergence of iterations or due to wave parameters lying outside the range of transformation matrices, it is not possible to transform all wave recordings from a source wave data location to a destination location.

\section{Comparison of Transformed and Recorded Wave Data}

Directional wave recordings at Galle had been conducted in deep water and can be considered as representative for a large coastal stretch. Therefore wave data transformed from Galle to any nearshore location on the southern coast can be considered to represent the wave climate at that location. However, wave recordings from the two nearshore locations at Kudawella and Hambantota need to be verified prior to transforming them to other locations. This verification process was carried out by transforming Galle wave data to Kudawella and Hambantota. The transformation was carried out on a 4 season basis, separately for sea and swell wave systems. The 4 seasons of the year considered were:

South West Monsoon season (SW) - (May to September)

Inter monsoon 1 Season (IM1) - (October to November)

North East Monsoon Season (NE) - (December to February)

Inter monsoon 2 Season (IM2) - (March to April)
The transformed wave data from Galle were then compared with actual wave recordings at these locations for the corresponding seasons. Since there was no overlap between any of these wave recordings, comparison was made on a statistical basis. Since Galle wave recordings are of a longer duration, it is likely that data transformed from Galle to Kudawella or Hambantota will contain higher waves than those recorded at these two locations. Therefore, in the statistical comparison only the directional distributions of waves were considered by comparing wave amplitudes.

The comparison of directional wave amplitudes indicated mismatches of wave amplitudes for sea waves at Kudawella and Hambantota for the SW monsoon season (Figures 4 and 5). A similar mismatch was also found at Hambantota for IM1 season.

Therefore, sea waves transformed from Galle to both Hambantota and Kudawella showed mismatch in direction distribution with recorded waves for SW monsoon sea waves. This is indicated in figures 4 and 5 . Additionally for sea waves in IM1 season also similar mismatch was found only at Hambantota. This is not indicated in a figure in order to limit the number of figures. Instead a case where directional distributions matched with each other for swell waves SW monsoon at Kudawella is indicated in Figure 6. Apart from wave data from Kudawella and Hambantota with this directional mismatch, all other wave data were transformed to all destination locations and combined on a seasonal basis for the two wave systems. 


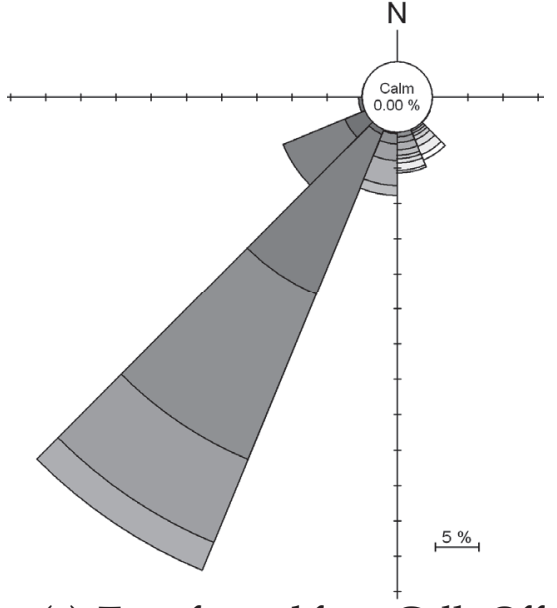

(a) Transformed from Galle Offshore

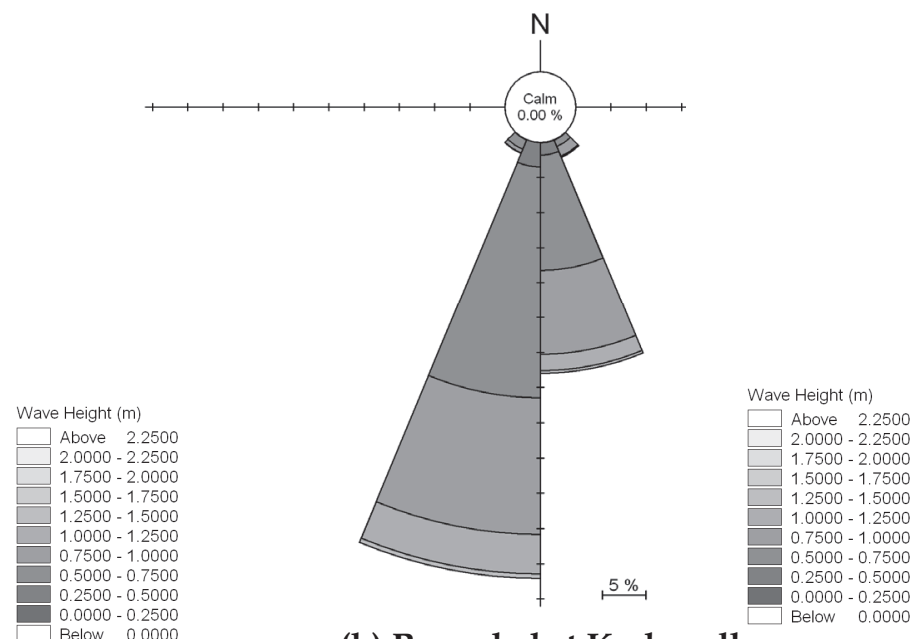

(b) Recorded at Kudawella

Figure 4 - Wave Roses for Kudawella at 15 m Water Depth for SW Monsoon Sea Waves

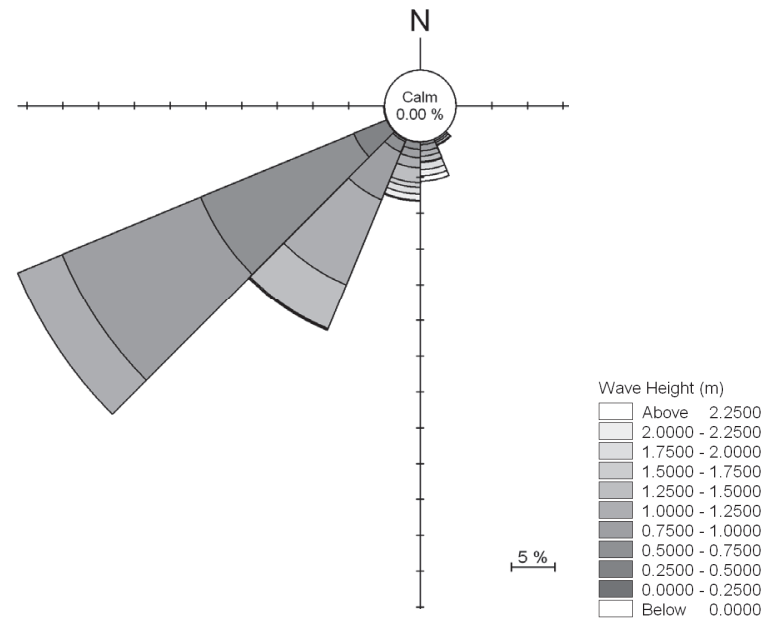

(a) Transformed from Galle Offshore

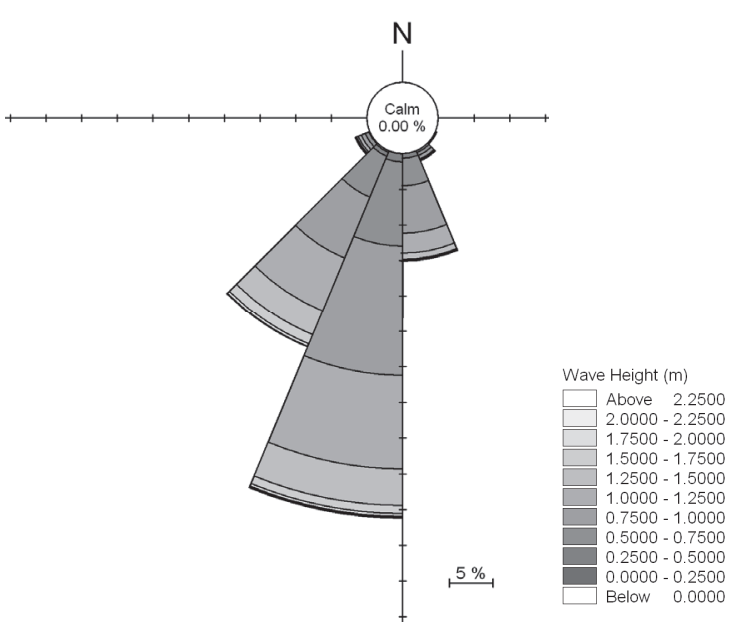

(b) Recorded at Hambantota

Figure 5 - Wave Roses for Hambantota at $17 \mathrm{~m}$ Water Depth for SW Monsoon Sea Waves

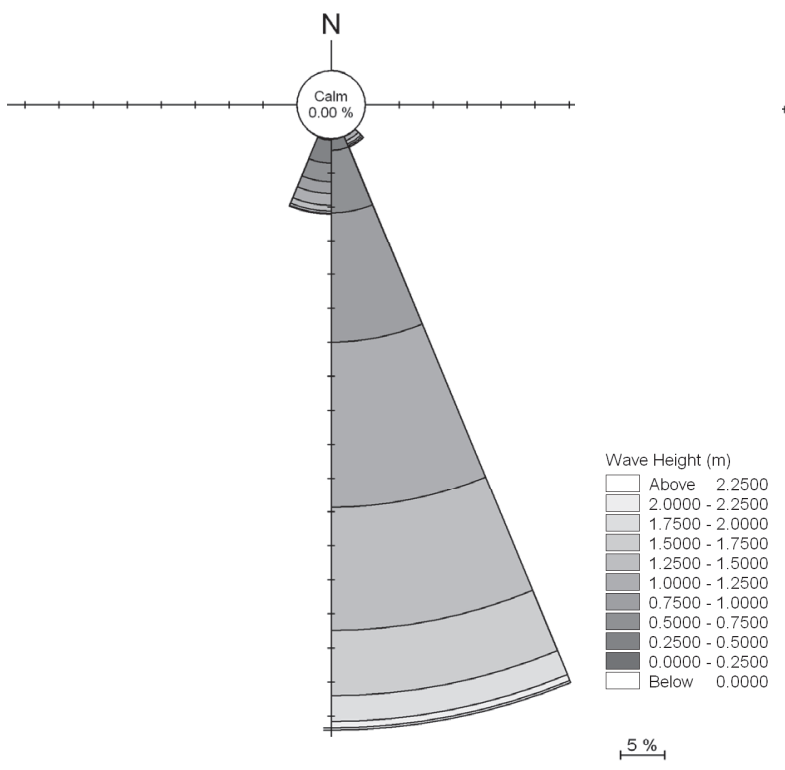

(a) Transformed from Galle Offshore

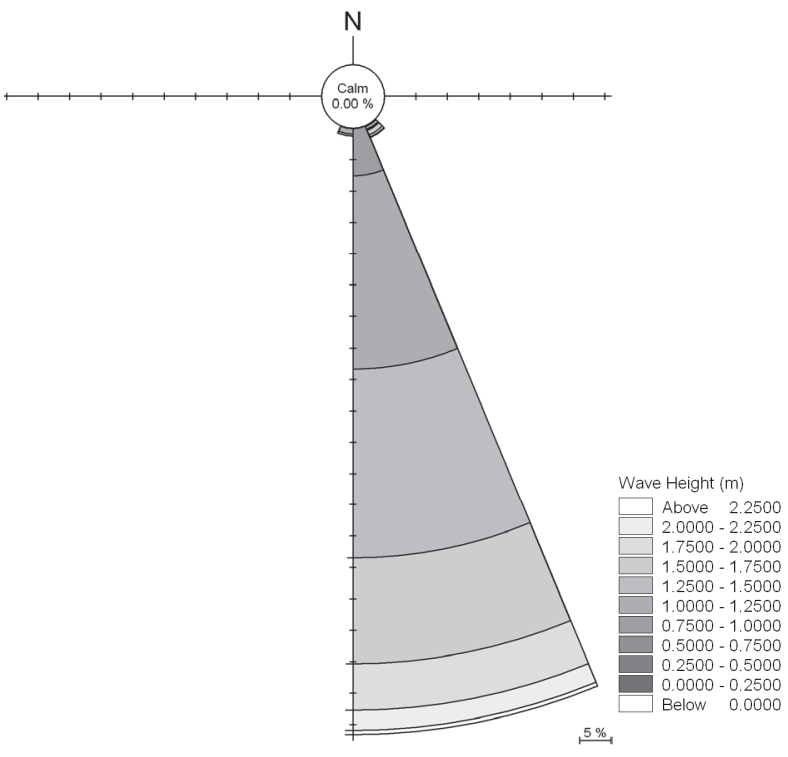

(b) Recorded at Kudawella

Figure 6 - Wave Roses for Kudawella at $15 \mathrm{~m}$ Water Depth for SW Monsoon Swell Waves 


\section{Nearshore Directional Wave Statistics}

Apart from wave data from Kudawella and Hambantota for the seasons which mismatched with transformed wave data from Galle offshore, all other wave data recordings were transformed to representative locations at $15 \mathrm{~m}$ water depth in selected coastal segments. The transformed wave data from different sources were combined and based on wave data time series obtained, directional wave statistics were obtained on a seasonal basis.

A rough estimate of relative strengths of sea and swell wave systems in any coastal segment can be obtained by consideration of two weighting factors. The first of these weighting factors is based on the comparison of square of the heights of average significant wave heights $\left(H_{m 0}\right)$ for sea and swell wave systems since wave energy is proportional to the square of the wave height. Accordingly:
Relative Weight 1 (sea waves) =

$$
\frac{\bar{H}_{m o, \text { sea }}^{2}}{\bar{H}_{m o, s e a}^{2}+\bar{H}_{m o, s w e l l}^{2}}
$$

Relative Weight 1 (swell waves) =

$$
\frac{\bar{H}_{m o, \text { swell }}^{2}}{\bar{H}_{m o, \text { sea }}^{2}+\bar{H}_{m o, \text { swell }}^{2}}
$$

The second relative weight is applied on a seasonal basis based on the fraction of number of days of the year contained in a particular season. Overall weighting factors on a seasonal basis were obtained by multiplication of the two weighting factors. The summation of these seasonal weighting factors results in overall annual weighting factors for the two wave systems. The results are given below for the coastal sectors W9, W1 and N7 in Tables 3 to 5.

\begin{tabular}{|c|c|c|c|c|c|c|c|c|}
\hline \multirow{3}{*}{ Season } & \multirow{2}{*}{\multicolumn{2}{|c|}{$\mathrm{H}_{\mathrm{m} 0}(\mathrm{~m})-$ Ave $^{* *}$}} & \multirow{2}{*}{\multicolumn{2}{|c|}{ Relative Weight 1}} & \multirow{2}{*}{\multicolumn{2}{|c|}{ Relative Weight 2}} & \multirow{2}{*}{\multicolumn{2}{|c|}{$\frac{\text { Combined }}{\text { Relative Weight }}$}} \\
\hline & & & & & & & & \\
\hline & Swell & Sea & Swell & Sea & Swell & Sea & Swell & Sea \\
\hline SW & 1.090 & 1.170 & 0.465 & 0.535 & 0.417 & 0.417 & 0.194 & 0.223 \\
\hline IM1 & 0.810 & 0.730 & 0.552 & 0.448 & 0.167 & 0.167 & 0.092 & 0.075 \\
\hline NE & 0.560 & 0.310 & 0.765 & 0.235 & 0.250 & 0.250 & 0.191 & 0.059 \\
\hline IM2 & 0.760 & 0.520 & 0.681 & 0.319 & 0.167 & 0.167 & 0.114 & 0.053 \\
\hline & & & \multicolumn{4}{|c|}{ Total } & 0.591 & 0.410 \\
\hline
\end{tabular}

Table 3 - Relative Strengths at Sea and Swell Waves in Coastal Segment W9

\begin{tabular}{|c|c|c|c|c|c|c|c|c|}
\hline \multirow{3}{*}{ Season } & \multirow{2}{*}{\multicolumn{2}{|c|}{$\mathrm{H}_{\mathrm{mr} 0}(\mathrm{~m})-\mathrm{Ave}^{* *}$}} & \multirow{2}{*}{\multicolumn{2}{|c|}{ Relative Weight 1}} & \multirow{2}{*}{\multicolumn{2}{|c|}{ Relative Weight 2}} & \multirow{2}{*}{\multicolumn{2}{|c|}{$\begin{array}{c}\text { Combined } \\
\text { Relative Weight }\end{array}$}} \\
\hline & & & & & & & & \\
\hline & Swell & Sea & Swell & Sea & Swell & Sea & Swell & Sea \\
\hline SW & 1.310 & 1.110 & 0.582 & 0.418 & 0.417 & 0.417 & 0.243 & 0.174 \\
\hline IM1 & 1.000 & 0.780 & 0.622 & 0.378 & 0.167 & 0.167 & 0.104 & 0.063 \\
\hline NE & 0.690 & 0.650 & 0.530 & 0.470 & 0.250 & 0.250 & 0.133 & 0.118 \\
\hline IM2 & 0.940 & 0.690 & 0.650 & 0.350 & 0.167 & 0.167 & 0.109 & 0.058 \\
\hline & & & & & Total & & 0.589 & 0.413 \\
\hline
\end{tabular}

Table 4 - Relative Strengths at Sea and Swell Waves in Coastal Segment W1

\begin{tabular}{|c|c|c|c|c|c|c|c|c|}
\hline \multirow{3}{*}{ Season } & \multirow{2}{*}{\multicolumn{2}{|c|}{$\mathrm{H}_{\mathrm{m} 00}(\mathrm{~m})-\mathrm{Ave}^{* *}$}} & \multirow{2}{*}{\multicolumn{2}{|c|}{ Relative Weight 1}} & \multirow{2}{*}{\multicolumn{2}{|c|}{ Relative Weight 2}} & \multirow{2}{*}{\multicolumn{2}{|c|}{$\begin{array}{c}\text { Combined } \\
\text { Relative Weight }\end{array}$}} \\
\hline & & & & & & & & \\
\hline & Swell & Sea & Swell & Sea & Swell & Sea & Swell & Sea \\
\hline SW & 0.820 & 0.620 & 0.636 & 0.364 & 0.417 & 0.417 & 0.265 & 0.152 \\
\hline IM1 & 0.660 & 0.520 & 0.617 & 0.383 & 0.167 & 0.167 & 0.103 & 0.064 \\
\hline NE & 0.430 & 0.580 & 0.355 & 0.645 & 0.250 & 0.250 & 0.089 & 0.161 \\
\hline IM2 & 0.610 & 0.520 & 0.579 & 0.421 & 0.167 & 0.167 & 0.097 & 0.070 \\
\hline & & & & & Total & & 0.554 & 0.447 \\
\hline
\end{tabular}

Table 5 - Relative Strengths at Sea and Swell Waves in Coastal Segment N7

** Ave - Average Significant Wave Height 
These coastal sectors were selected to demonstrate clearly the spatial variation of wave heights, as W9 and N7 are located at extreme ends of southern coast and W1 at the centre of the southern coast.

The results extracted from the above analysis given in Tables 3 to 5 indicate that swell waves are somewhat stronger compared to sea waves in terms of contribution to the annual wave energy, although considerably high sea waves do occur during south west monsoon season. Moving towards the south eastern part of the southern coast marked influence of north east monsoonal sea waves is seen. This is clearly indicated in Table 5 for the north east monsoon season for the N7 coastal segment, where sea waves are seen to contribute more than 75 percent of wave energy compared to swell waves.

\section{Nearshore Extreme Waves}

The extreme occurrences of waves need to be assessed in the design of coastal and marine structures. The extreme wave heights can be determined by extrapolating the peak wave heights occurring during storm events using appropriate probability distributions. In the case of swell waves high waves have occurred more or less during south west monsoon season. This is also true for the sea waves as well. However, north east monsoonal wind= induced extreme sea waves are important in the south eastern part of the southern coast due to their distinctly different direction of approach.

Extreme wave heights were determined by using Gumbel and Weibull probability distributions to extrapolate peak wave heights occurring in independent storm events exceeding a selected threshold wave height (Kamphuis, [1]). The probability of exceedance, which is the probability that any wave height $H^{\prime}$ exceeding a specified wave height $H$ as per these two probability distributions is given by:

Gumbel Distribution:

$Q=Q\left(H^{\prime}>H\right)=1-\exp \left\{-\exp \left[-\frac{H-\gamma}{\beta}\right]\right\}$

Weibull Distribution:

$Q=Q\left(H^{\prime}>H\right)=1-\exp \left\{-\left[-\frac{H-\gamma}{\beta}\right]^{\alpha}\right\}$
Where $\alpha, \beta$ and $\gamma$ are the parameters of the distributions.

In the application of this method, selected $N$ numbers of peak wave heights were arranged in the descending order of magnitude with an assigned ranking of 1 for the highest wave height and the lowest wave height receiving the rank $N$. The probability of exceedance $Q$ is defined as:

$Q=\frac{i-c_{1}}{N+c_{2}}$

The values of the constants $c_{1}$ and $c_{2}$ for the two probability distributions were estimated as:

Gumbel Distribution: $\quad c_{1}=0.44$ and $c_{2}=0.12$

Weibull Distribution: $\quad c_{1}=0.2+0.27 / \alpha \quad$ and $c_{2}=0.2+0.23 / \alpha$

The parameters $\beta$ and $\gamma$ of the Gumbel Distribution were determined by linear regression analysis based on a rearranged form of Eq. (3). In the case of Weibull Distribution, for specified value of $\alpha$, the parameters $\beta$ and $\gamma$ were determined by a similar procedure based on Eq. (4). Upon determination of parameters of the probability distributions, the wave heights of any desired return period $T_{R}$ in years can be computed from Eqs. (3) or (4) as appropriate since the probability of exceedance $Q$ is related to return period as:

$Q=\frac{1}{\lambda T_{R}}$

In which, $\lambda$ is the number of storm events per year, which is known since the duration of the transformed wave height time series is known. For a particular set of selected peak wave heights of storm events Gumbel and Weibull Distributions (for varying values of parameter $\alpha$ ) were applied to predict extreme wave heights of different return periods. The set of extreme wave heights resulting from the highest coefficient of correlation in the regression analysis was selected as the most representative. The summarized results for the three selected coastal sectors are tabulated for the coastal sectors W9, W1 and N7 in Tables 6 to 8 . It should be noted that coastal sectors W9 and W1 are hardly influenced by NE monsoon sea waves and therefore extreme wave heights were not determined for this season. 
Table 6 - Extreme Significant Wave Heights for Sea and Swell Waves in Coastal Segment W9

\begin{tabular}{|c|c|c|c|c|c|c|}
\hline \multirow[t]{2}{*}{ Wave Conditions } & \multicolumn{6}{|c|}{$\begin{array}{c}\text { Extreme Wave Heights (m) for Different Return } \\
\text { Periods (Years) }\end{array}$} \\
\hline & $1 Y_{r}$ & $5 \mathrm{Yr}$ & $10 \mathrm{Yr}$ & $25 \mathrm{Yr}$ & $50 \mathrm{Yr}$ & $100 \mathrm{Yr}$ \\
\hline $\begin{array}{l}\text { Sea Waves - SW Monsoon Season } \\
\text { Probability Distribution: Weibul }(\alpha=1.4) \\
\text { Correlation Coefficient: } 0.9915\end{array}$ & 2.41 & 2.67 & 2.78 & 2.90 & 2.99 & 3.08 \\
\hline $\begin{array}{l}\text { Swell Waves - SW Monsoon Season } \\
\text { Probability Distribution: Weibul }(\alpha=0.8) \\
\text { Correlation Coefficient: } 0.9643\end{array}$ & 2.43 & 3.01 & 3.30 & 3.70 & 4.02 & 4.35 \\
\hline
\end{tabular}

Table 7 - Extreme Significant Wave Heights for Sea and Swell Waves in Coastal Segment W1

\begin{tabular}{|c|c|c|c|c|c|c|}
\hline \multirow[t]{2}{*}{ Wave Conditions } & \multicolumn{6}{|c|}{$\begin{array}{c}\text { Extreme Wave Heights (m) for Different Return } \\
\text { Periods (Years) }\end{array}$} \\
\hline & $1 Y_{r}$ & $5 \mathrm{Yr}$ & $10 \mathrm{Yr}$ & $25 \mathrm{Yr}_{\mathrm{r}}$ & $50 \mathrm{Yr}$ & $100 \mathrm{Yr}_{\mathrm{r}}$ \\
\hline $\begin{array}{l}\text { Sea Waves - SW Monsoon Season } \\
\text { Probability Distribution: Weibul }(\alpha=1.0) \\
\text { Correlation Coefficient: } 0.9835\end{array}$ & 2.19 & 2.53 & 2.68 & 2.87 & 3.02 & 3.17 \\
\hline $\begin{array}{l}\text { Swell Waves - SW Monsoon Season } \\
\text { Probability Distribution: Weibul }(\alpha=1.4) \\
\text { Correlation Coefficient: } 0.9814\end{array}$ & 2.70 & 2.96 & 3.06 & 3.18 & 3.27 & 3.35 \\
\hline
\end{tabular}

Table 8 - Extreme Significant Wave Heights for Sea and Swell Waves in Coastal Segment N7

\begin{tabular}{|c|c|c|c|c|c|c|}
\hline \multirow[t]{2}{*}{ Wave Conditions } & \multicolumn{6}{|c|}{$\begin{array}{c}\text { Extreme Wave Heights (m) for Different Return } \\
\text { Periods (Years) }\end{array}$} \\
\hline & $1 \mathrm{Yr}$ & $5 \mathrm{Yr}$ & $10 \mathrm{Yr}$ & $25 \mathrm{Yr}$ & $50 \mathrm{Yr}$ & $100 \mathrm{Yr}$ \\
\hline $\begin{array}{l}\text { Sea Waves - SW Monsoon Season } \\
\text { Probability Distribution: Weibul }(\alpha=2.0) \\
\text { Correlation Coefficient: } 0.9884\end{array}$ & 2.06 & 2.21 & 2.25 & 2.31 & 2.36 & 2.40 \\
\hline $\begin{array}{l}\text { Swell Waves - SW Monsoon Season } \\
\text { Probability Distribution: Weibul }(\alpha=2.0) \\
\text { Correlation Coefficient: } 0.9878\end{array}$ & 1.60 & 1.72 & 1.75 & 1.80 & 1.83 & 1.85 \\
\hline $\begin{array}{l}\text { Sea Waves - NE Monsoon Season } \\
\text { Probability Distribution: Weibul }(\alpha=0.5) \\
\text { Correlation Coefficient: } 0.9823\end{array}$ & 1.27 & 1.52 & 1.70 & 2.02 & 2.31 & 2.65 \\
\hline
\end{tabular}




\section{Conclusions}

The variability of wave climate along the southern coast of Sri Lanka was assessed through numerical wave propagation modelling making use of wave recordings available at three locations in the study area. Although information on offshore wave climate in the study area was not available, through the application of wave transformation matrix approach, it was possible to transform waves to any desired location from the three source wave data locations at Galle, Kudawella and Hambantota. The study findings are useful in assessing extreme wave conditions, annual and seasonal wave climate for littoral drift calculations and shoreline changes in different sectors of the study area.

\section{References}

1. Kamphuis, William, J., "Introduction to Coastal Engineering and Management", World Scientific, Singapore, 2002, pp. 81-100.

2. Lanka Hydraulic Institute (LHI), “Hambantota Seaport Development Phase I - Mathematical Model Test on Wave Field", A Report prepared for Sri Lanka Ports Authority, 2007.

3. Scheffer, H-J., Fernando, K.R.M.D., and Fittschen, T., "Directional Wave Climate Study South West Coast of Sri Lanka", Sri Lankan German Cooperation, CCD_GTZ Coast Conservation Project, 1994.

4. www.spc.noaa.gov/faq/tornado/beaufort.html, August 2010. 